Ghost Dances and Identity 
The publisher gratefully acknowledges the generous

contribution to this book provided by the General Endowment Fund of the University of California Press Foundation. 


\section{Ghost Dances and Identity}

Prophetic Religion and

American Indian Ethnogenesis

in the Nineteenth Century

Gregory E. Smoak 
University of California Press, one of the most distinguished university presses in the United States, enriches lives around the world by advancing scholarship in the humanities, social sciences, and natural sciences. Its activities are supported by the UC Press Foundation and by philanthropic contributions from individuals and institutions. For more information, visit www.ucpress.edu.

University of California Press

Berkeley and Los Angeles, California

University of California Press, Ltd.

London, England

(C) 2006 by The Regents of the University of California

Library of Congress Cataloging-in-Publication Data

Smoak, Gregory E., I962-

Ghost dances and identity : prophetic religion and American Indian ethnogenesis in the nineteenth century / Gregory E. Smoak.

p. $\mathrm{cm}$.

Includes bibliographical references and index.

ISBN 0-520-24658-6 (cloth : alk. paper)

I. Ghost dance-History- I9th century. 2. Shoshoni Indians-Rites and ceremonies. 3. Shoshoni IndiansReligion. 4. Shoshoni Indians-Ethnic identity.

5. Bannock Indians-Rites and ceremonies.

6. Bannock Indians-Religion. 7. Bannock

Indians-Ethnic identity. I. Title.

E99.S4S64 2005

299.7'98'09034-dc22

2005011962

Printed and bound in Canada

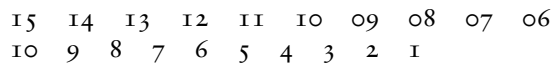

This book is printed on New Leaf EcoBook 6o, containing $60 \%$ post-consumer waste, processed chlorine free; $30 \%$ de-inked recycled fiber, elemental chlorine free; and I०\% FSC-certified virgin fiber, totally chlorine free. EcoBook 60 is acid-free and meets the minimum requirements of ANSI/ASTM D5634-OI (Permanence of Paper). 
For Janet M. Everts Smoak

and Floyd A. O'Neil 
